\title{
RHEOLOGICAL PROPERTIES OF MIXTURES OF RANDOM POLYPROPYLENE WITH BUTADIENE-NITRILE RUBBER AND VULCANIZATES BASED ON THEM
}

\author{
A.J.Quliyev, N.T.Kakhramanov, *N.S.Koseva, N.B.Arzumanova \\ Institute of Polymer Materials, NAS of the Azerbaijan \\ *Institute of Polymers, Sofia, Bulgaria \\ najaf1946@rambler.ru
}

Received 21.07.2020

Accepted 30.10.2020

\begin{abstract}
The paper presents the results of studying the effects of butadiene-nitrile rubber concentration and temperature on the flow curves of the random polypropylene-based polymer blends. To improve the technological compatibility of polymer blends, a graft(ed) copolymer of polypropylene with maleic anhydride was used as a compatibilizer. Melt viscosity as a function of temperature and shear rate is shown, and the activation energy of a viscous flow has been defined. A generalized temperature-invariant characteristic of the viscosity properties of polymer blends has been plotted. This makes it possible to predict the value of their effective viscosity at high shear rates, close to real processing conditions.
\end{abstract}

Keywords: butadiene-nitrile rubber, compatibility, melt viscosity, rheology, activation energy, compatibilizer.

doi

\section{Introduction}

In recent years, the attention of many scientists around the world has been paid to studying the structure and properties of incompatible polymer composites based on polyolefins and polar elastomers. The interest to such materials is primaly the fact that they enable to formation of properties in the composites completely different in nature of their polymers [1-3]. These composites include blends based on thermoplastic polyolefins and polar elastomers - butadiene-nitrile, butadiene-styrene rubbers, etc. But, along with this, there are problems related to their miscibility and technological compatibility. The lack of the required technological compatibility of the blend components causes the stratification of blends during blending. This phenomenon naturally affects the basic physical and mechanical properties of the blends $[4,5]$. To achieve the required level of technological compatibility in polymer blends, the most effective is the use of small amounts of compatibilizers, which are, as a rule, graft copolymers. The latter circumstance enables not only to achieve the required intermiscibility and technological compatibility, but also to significantly improve the rheological properties of polymer blends. At working out polymer blends based on a thermoplastic polyolefin and a polar elastomer, the other important problems related to production of thermoplastic elastomers are solved. These elastostomers not only have elastic properties, they are also processed as thermosplastics on equipment by such methods as extrusion and injection moulding [6-9].

Despite the importance of the problem under consideration, the references provide very limited information on the rheological properties of thermoplastic elastomers and vulcanizates based on them. Therefore, in this paper, the main attention is paid to studying the rheological features of the flow of thermoplastic elastomers and vulcanizates based on them.

\section{Experimental part}

Random polypropylene (RPP), or a thermoplastic statistical ethylene-RP2400 with propylene copolymer is characterized by the following properties: ultimate tensile stress -28.5 $\mathrm{MPa}$, tensile strain $-600 \%$, MFI $-1.78 \mathrm{~g} / 10 \mathrm{~min}$, density $-0.904 \mathrm{~g} / \mathrm{cm}^{3}$, melting point $-146^{\circ} \mathrm{C}$, heat Vicat resistance according to $-131^{\circ} \mathrm{C}$.

SKN is a butadiene-nitrile rubber containing a $40 \%$ acrylonitrile (SKN-40). 
Exxelor PO1200 compatibilizer is intended for use as a binding agent in order to improve the compatibility of polymeric materials and the reactivity under interacting with inorganic fillers.

This is achieved in a reactive extrusion process by the graft copolymerization of polypropylene containing maleic anhydride (MA). The MA concentration in the compatibilizer is 3.0 mass $\%$.

Polymer composites based on RPP+SKN were obtained in the process of blending on rollers at $170^{\circ} \mathrm{C}$. After the melting of RPP, 2.0 mass\% PMPA was added, and then, in the process of intensive mixing SKN crumbs were added on rollers for $8 \mathrm{~min}$. To obtain vulcanizates 2.0 mass\% sulfur was additionally added during blending.

Rheological studies of polymeric materials were carried out using INSTRON (Italy) rheometer, a capillary rheometer, MELT FLOW TESTER, CEAST MF50 within $170-230^{\circ} \mathrm{C}$ temperature range and under $2.16-21.6 \mathrm{~kg}$ loads.

\section{Results and its discussion}

It is quite obvious that the lack of systematic studies on the rheology of polymer blends, in a number of cases, does not allow to give theoretical validation of those processes that occur during melting. At as a minimum, these are three-component blends consisting of a thermoplastic, an elastomer and a compatibilizer. The use of a low molecular weight grafted copolymer based on polypropylene and maleic anhydride (PP-g-MA) as a compatibilizer promotes an increase in the adhesive contact between the dispersed phase of SKN and the dispersed medium of RPP, that ultimately significantly improves the technological compatibility of the mixed components of the mixture. In a viscous-flow state, the main purpose of PP-gMA is the manifestation of plasticizing properties improve the rheological properties of polymer blends. This is due to the fact that PP-gMA is a low molecular weight polymer with MFI=36 g/10 min, allows it to exhibit the properties of an internal lubricant agent.

There is reason to believe that the polar MA units will be located in the SCN boundary phase, and the polypropylene segments, that do not contain grafted units, will be distributed in the RPP dispersed medium. In this case, the purpose of the compatibilizer, as a low molecular weight PP-g-MA, is not only to increase the adhesive contact in the interface region, but also to plasticization of the composite material [10]. In this case, the blends based on RPP+40 mass\% SKN-40 exhibit the properties of dynamically vulcanized thermo elastoplasts (DVEP). As a lubricant agent, PP-g-MA helps maintain the melt fluidity of polymer blends and DVEP at a level acceptable for processing. So, for example, as a result of experimental studies of the MFI polymer blends, it was found that the MFI of a compatibilized polymer blend of RPP+40 mass \% SKN-40 after sulfuric vulcanization was 0.7-1.2 g/10 min, while for the unmodified composition the value of this indicator was very low, i.e. within $0.1-0.3 \mathrm{~g} / 10 \mathrm{~min}$.

Figure $1(a, b)$ shows microphotographs of the polymer blend before (Figure $1 a$ ) and after (Figure $1 b$ ) vulcanization. From Figure $1 a$, in the presence of PP-g-MA, the finely dispersed elastomeric phase is located in the form of islands in a RPP dispersed medium. Such supramolecular structure explains the increase in the elasticity of the polymer blend responsible for the deformation properties of the composite material [10-12]. It should be noted that in the process of sulfur vulcanization, the crosslinking occurs at the site of the breaking of the double bonds contained in the SKN macromolecule. Selective crosslinking takes place for the simple reason that in comparison with SKN, RPP macrochains do not have vinyl groups [12]. In addition, sulfur is an 8-membered cycle which, under the action of shear stresses and temperature, decomposes and is followed by the formation of radicals that initiate breaking and crosslinking at double bonds. Taking into consideration the selective nature of the crosslinking process, a DVEP based on $\mathrm{RPP}+\mathrm{SKN}-40$ has been obtained as a result of mechanochemical synthesis. Figure $1 b$ shows a microphotograph for the vulcanizate of this blend. Comparing these images, it can be seen that, as a result of sulfur vulcanization, crosslinked elastomeric formations behave as fine fillers in the RPP 
composition. The peculiarity of sulfuric vulcanization is manifested in the fact that crosslinking selectively occurs mainly at the site of breaking the SKN double bonds. In other words, the crosslinked dispersed phase of SKN in a RPP dispersed medium behaves like an elastic filler. Such a structural organization is a DVEP characteristics that significantly affects the regularity of changes in rheological characteristics, especially of sulfur vulcanizates $\mathrm{RPP}+\mathrm{SKN}$.

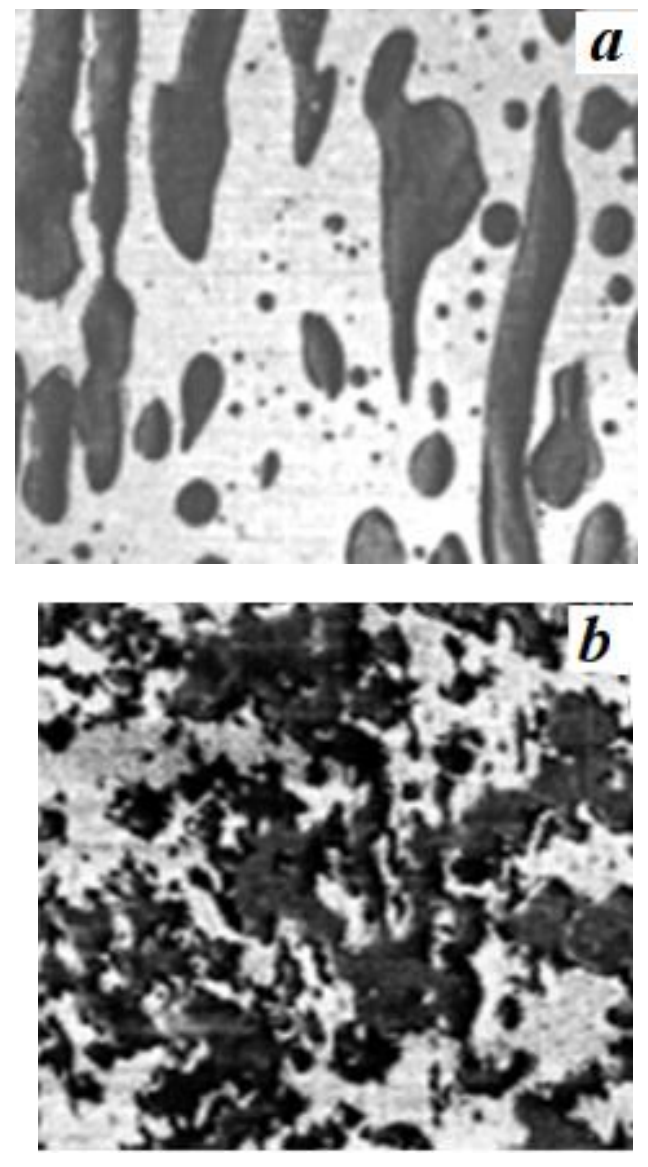

Fig. 1. Microphotographs of compatibilized polymer mixture RPP+40\%mass. SKN-40 (a) and sulfuric vulcanizaites based on them $(b)$.

For a comprehensive analysis of the rheological properties of the considered polymer mixtures, Figure 2 shows the flow curves of $\mathrm{RPP}+\mathrm{SKN}-40$ polymer mixtures with different contents of the elastomeric component. From a comparative analysis of the flow curves in this figure, it can be seen that at low shear stresses, the largest Newtonian flow region is not fixed. Moreover, with an increase in the concentration of SKN-40 in the composition of the RPP, a monotonic decrease in the shear rate is observed. It is characteristic that the flow curves of polymer mixtures are located between the flow curves of the initial RPP (Figure 2,1) and the initial SKN-40 (Figure 2,5). Such a uniform change in the flow pattern of polymer mixtures depending on the shear stress and concentration of SKN-40 indicates good compatibility of the components of the mixture in the presence of PP-g-MA.

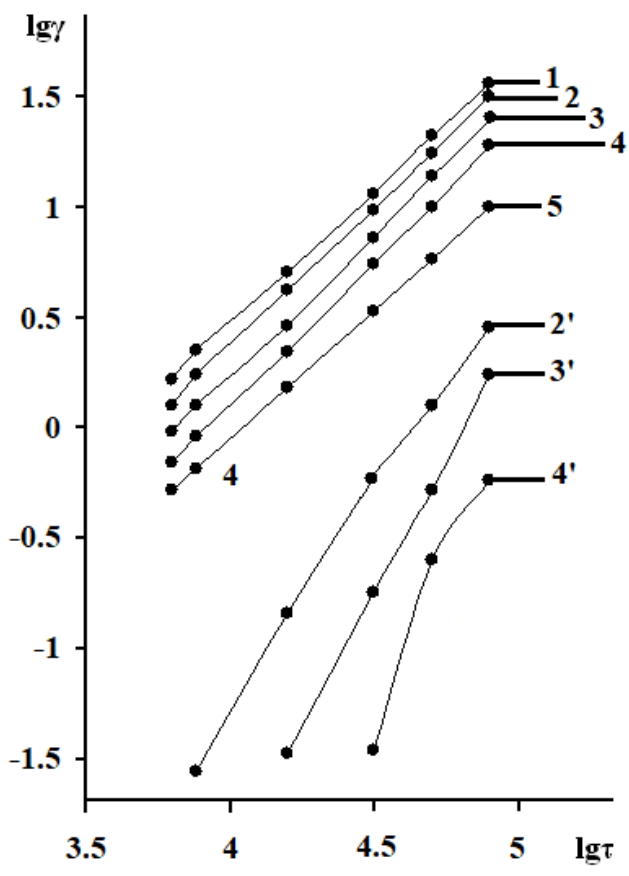

Fig. 2. Flow curves of the RPP+SKN-40+PPg-MA (1-5) polymer blends and sulfur vulcanizates based on them $\left(2^{\prime}-4\right.$ ') with different content of elastomer, mass \%: 1(o) initial RPP; 2,2' - 20; 3,3' - 30; 4,4' - 40; 5 initial SKN-40.

For a comprehensive analysis of the rheological properties of the considered polymer blends, Figure 2 shows the flow curves of $\mathrm{RPP}+\mathrm{SKN}-40$ polymer blends with different content of the elastomeric component. From a comparative analysis of the flow curves given in this figure, it is seen that at low shear stresses, the largest Newtonian flow region is not fixed. At the same time, with an increase in the concentration of SKN-40 in the RPP composi- 
tion, a monotonic decrease in the shear rate is observed. It is characteristic that the flow curves of polymer blends are between the flow curves of the initial RPP (Figure 2,1) and the initial SKN-40 (Figure 2,5) polymers. Such a uniform change in the flow pattern of polymer blends in dependence in the shear stress and the SKN-40 concentration indicates good compatibility of the blend components in the presence of PP-g-MA.

The same figure shows the flow curves of sulfur vulcanizates of polymer blends (Figure 2, curves 2'-4'). As expected, vulcanizates are characterized by lower shear rates. With this, the higher the content of the elastomeric component in the vulcanizate, the significantly lower the shear rate becomes. Such a high sensitivity of the shear rate of vulcanized samples to the concentration of the elastomeric component and the shear stress is primarily connected with a special nature of the formation of flexible structural units, or associates, in the melt. The difference is in the fact that the mechanism of the emergence and decay of associates in vulcanized systems is fundamentally distinguish out from the flow mechanism of the conventional homopolymers. This is due to the fact that in the process of sulfur vulcanization, crosslinked elastomeric associates are formed which, apparently, differ separately in resistance to thermal fluctuation decomposition and behave like the filler particles. However, we assume that crosslinked elastomeric associates in the melt, due to polar nitrile groups and adhesive forces can be combined into "macroassociates" which, like associates formed from the RPP macrochains, can undergo thermal fluctuation decay and recovery. In this connection, we believe that it definitely results from exposure to high shear stresses whereafter macroassociates decompose into individual associates, thereby contributing to a noticeable increase in the shear rate. For this, with an increase in shear stress, an almost linear increase in the shear rate of vulcanizates containing 20-30 mass \% SKN-40 occurs. For the SKN-40 concentration equal to 40 mass $\%$, delinearization is observed. This phenomenon can be probably interpreted by the formation, as mentioned above, of the spontaneous thermofluctuation decay of macroassociates.

Figure 3 shows the flow curves of the RPP+40 mass\% SKN-40+2.0 mass \% PP-g-MA polymer blend within the $170-230^{\circ} \mathrm{C}$ tempera-

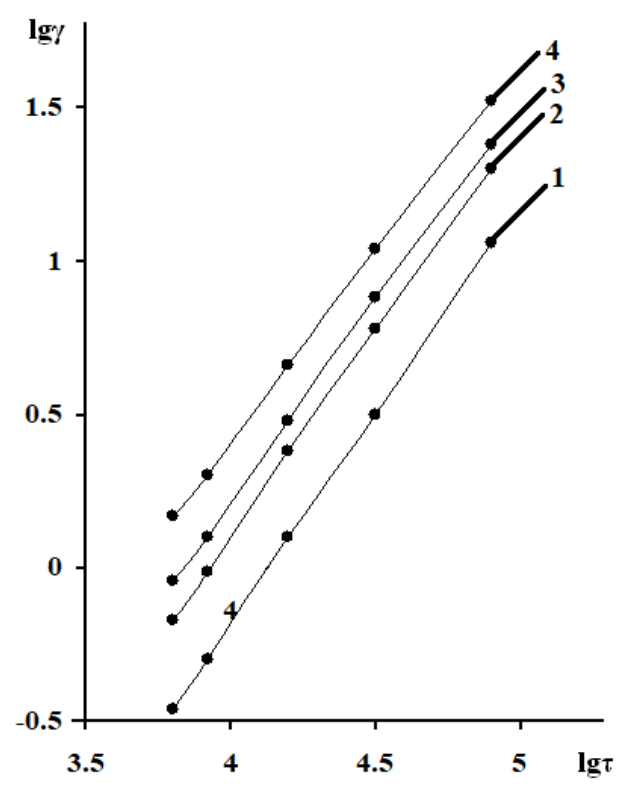

Fig. 3. Flow curves of the polymer mixture $\mathrm{RPP}+\mathrm{SKN}-40+\mathrm{PP}-\mathrm{g}-\mathrm{MA}$ at various temperatures, ${ }^{0} \mathrm{C}: 1$ - 170, 2 - 190, 3 - 210, 4 $230^{\circ} \mathrm{C}$.

ture range. Analyzing the curves in this figure, you can see that for a constant shear stress $(\lg \tau=4.5)$ with increasing the temperature and shear stress, an increase in the shear rate of the polymer blend melt is observed. From this figure, it can be established that, regardless of the temperature and shear stress, the Newtonian flow region is not observed. In addition, if we pay attention to the flow curve of the composition at $170^{\circ} \mathrm{C}$ (Figure 3.1), we can see that in the entire range of shear stresses at this temperature, the shear rate is noticeably lower. This circumstance indicates that at this temperature the melt viscosity increases so much that certain difficulties arise with the movement of the associates in macrochains during the process of uniaxial deformation in a capillary.

For more information on the flow nature of polymer blends, on the Figure 4 shows the 


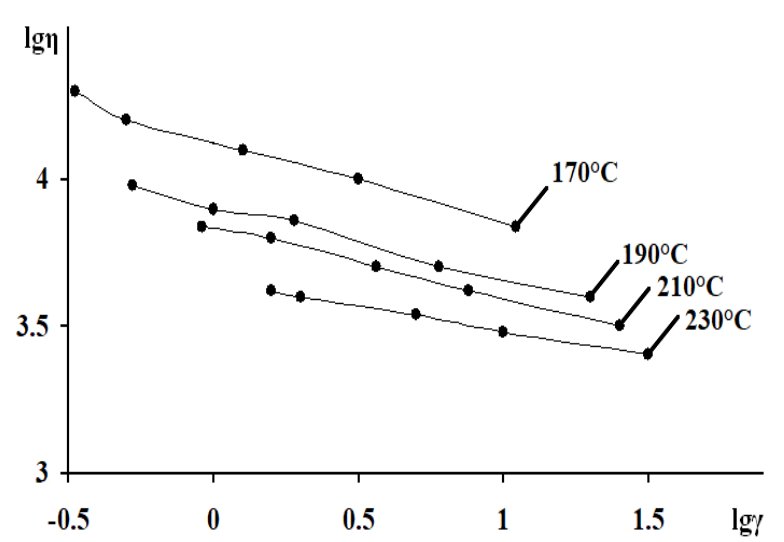

Fig. 4. Dependence of the viscosity of the polymer mixture RPP+SKN-40+PP-g-MA on the shear rate at various temperatures: $1-170,2-190,3-210$, $4-230^{\circ} \mathrm{C}$.

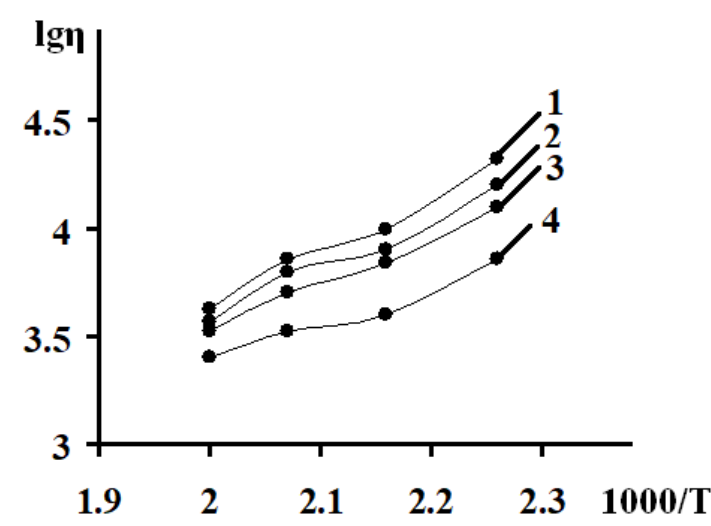

Fig. 5. Dependence of viscosity on inverse temperature at various values of shear stress, $\lg \tau: 1-3.8,2-3.9,3-4.5,4-4.9$.

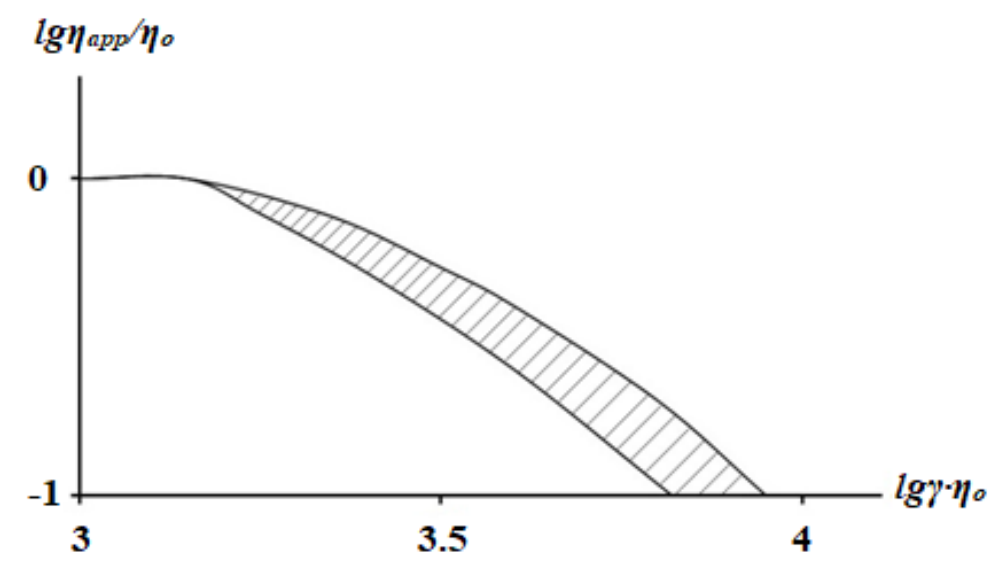

Fig. 6. Generalized temperature-invariant characteristic of the viscosity properties of polymer mixtures and vulcanizates based on RPP+SKN-40 mixtures.

dependence of the melt viscosity on shear rate in logarithmic coordinates in the $170-230^{\circ} \mathrm{C}$ temperature range. The dependency curves in this figure are mainly presented in the form of a linear relationship, that also confirms our arguments related to the uniform dispersion of the elastomeric component in the RPP composition. In the contrary case, nonuniform and nonlinear dependences of the melt viscosity on the shear rate were observed.

Another important rheological characteristic of polymers is the activation energy of viscous flow, which is determined from the dependence of the melt viscosity on the inverse temperature (Figure 5). The activation energy of viscous flow determined from the FrenkelEyring equation characterizes the structural state of the associates in macrochains during its uniaxial deformation. According to this theory, the movement of molecules in liquid is mainly determined by two factors: the first one is volume-free macrochains in the volume of the liquid given, and the latter is overcoming the forces of intermolecular interaction [13-15]. From the analysis results obtained, it follows that the apparent activation energy of viscous flow in the temperature range of $210-230^{\circ} \mathrm{C}$ is 51 $\mathrm{kJ} / \mathrm{mol}$, while in the temperature range of 190 $210^{\circ} \mathrm{C}$ this value varies within $22-24 \mathrm{~kJ} / \mathrm{mol}$, and is $49-68 \mathrm{~kJ} / \mathrm{mol}$ at $170-190^{\circ} \mathrm{C}$.

Numerous experiments on polymer rheology, carried out under the guidance of professors G.V.Vinogradov and A.Ya.Malkin, have shown that the change in the viscosity of various polymer melts under the influence of deformation is convenient to be compared when 
assessing the ratio of the apparent viscosity $\left(\eta_{\text {app }}\right)$ to its maximum value $\left(\eta_{\mathrm{o}}\right)$. The ratio $\eta_{\text {app }} / \eta_{\text {o }}$ qualitatively characterizes the deviation degree of the viscosity of the polymer melt from the highest Newtonian viscosity [13-15].

Figure 6 shows the temperature-invariant characteristic of the viscosity properties of thermoplastic elastomers based on $\mathrm{RPP}+\mathrm{SKN}$ 40. Analysing this figure, we can established that the form of this function does not depend on temperature, and therefore, it is called invariant in relation to temperature.

As you can see from the figure, with an increase in the reduced shear rate $\gamma \cdot \eta_{\mathrm{o}}$, a monotonic decrease in the reduced viscosity $\eta_{\text {app }} / \eta_{\mathrm{o}}$ is observed. The existence of a temperatureinvariant characteristic of the melt of polymer blends considered indicates a qualitatively identical nature of the destruction of associates in a viscous-fluid state.

\section{Conclusion}

Thus, on the basis of the above-mentioned, we can conclude that the regularity of changes in the flow curves and viscosity of the melt of RPP+SKN polymer blends and their vulcanizates, depending on the shear stress, temperature and the ratio of the mixture components, has been investigated. It is shown that, as a result of sulfur vulcanization of the RPP+SKN-40+PPg-MA mixture, it is possible to obtain DVEP, the rheological properties of which make it possible to process them using standard equipment by injection moulding and extrusion methods. The results of a theoretical analysis of the flow mechanism of RPP+SKN polymer blends and vulcanizates based on them are presented. The activation energy of the viscous flow of the initial RPP+SKN polymer blends has been determined. A temperature-invariant characteristic which allows predicting the viscosity properties of polymer blends in relation to the real conditions of their processing by injection moulding and extrusion has been plotted.

\section{References}

1. Simonov-Emel'janov I.D. Postroenie struktur v dispersno-napolnennyh polimerah i svojstva kompozicionnyh materialov. Plasticheskie massy. 2015. No 9-10. S. 29-36.
2. Simonov-Emel'janov I.D. Parametry reshetki i struktury dispersno-napolnennyh polimernyh kompozicionnyh materialov s reguliruemym kompleksom svojstv. Konstrukcii iz kompozicionnyh materialov. 2019. No 3. S. 37-46.

3. Volkova N.V., Emel'janov D.N., Molodova A.A. Fazovoe sostojanie i reologicheskie svojstva smesej polimetakrilatov, obrazujushhihsja v processe polimerizacii. Vestnik nizhegorodskogo universiteta im. N.Lobachevskogo. 2014. No 4. S. 154-158.

4. Rudakova T.A., Evtushenko Ju.M., Grigor'ev Ju.A., Ozerin A.N. Polijetilen nizkogo davlenija, modificirovannyj organomontmorillonitom. Vse materialy. Enciklopedicheskij spravochnik. 2018. No 8. S. 12-16.

5. Spiridonov A.M., Sokolova M.D., Ohlopkova A.A. Polimernye kompozicionnye materialy na osnove sverhvysokomolekuljarnogo polijetilena, napolnennogo organomodificirovannym ceolitom. Vse materialy. Enciklopedicheskij spravochnik. 2019. No 8. S. 7-11.

6. Kakhramanov N.T., Azizov A.G.,Osipchik V.S., Mammadli U.M., Arzumanova N.B. Nanostructured composites and polymer materials. Int. Polymer Sci. and Technology. 2017. V. 44. No 2. P. 37-47.

7. Vol'fson S.I., Ohotina N.A., Panfilova O.A., Vahitov I.I. Sposoby poluchenija termoplastichnyh vulkanizatov na osnove smesi kauchukov i polipropilena. Vestnik kazanskogo tehnologicheskogo universiteta. 2015. V. 18. No 14. S. 90-92.

8. Kahramanly Ju.N. Nesovmestimye polimernye smesi i kompozicionnye materialy na ih osnove. Baku: Jelm. 2013. $152 \mathrm{~s}$.

9. Vol'fson S.I. Dinamicheski vulkanizovannye termoelastoplasty: poluchenie, pererabotka, svojstva. M.: Nauka, 2004. $170 \mathrm{~s}$.

10. Kahramanov N.T., Guliev A.D., Osipchik V.S. Dinamicheski vulkanizovannye jelastoplasty na osnove tehnologicheski sovmestimogo random polipropilena i butadien-nitril'nogo kauchuka. Plasticheskie massy. 2019. No 11-12. S. 30-33.

11. Gusejnova Z.N., Kahramanov N.T., Guliev A.D., Kurbanova R.V. Termomehanicheskie svojstva polimernyh smesej na osnove termoplastichnyh poliolefinov i butilkauchuka. Vse materialy. Enciklopedicheskij spravochnik. 2019. No 3. S. 2-9.

12. Kahramanov N.T., Arzumanova N.B., Osipchik V.S. Reologicheskie svojstva kompozitnyh materialov na osnove random polipropilena i vezuviana. Perspektivnye materialy. 2017. No 4. S. 35-47.

13. Malkin A.Ja. Osnovy reologii. SPb.: Professija. 2018. $336 \mathrm{~s}$.

14. Dolomatov M.Ju., Dezorcev S.V. Termodinamika vjazkotekuchego sostojanija. Bashkirskij himicheskij zhurnal. 2010. V. 17. No 3. S. 67-71.

15. Bessonova N.P., Krashennikov S.V., Korobko A.P. Struktura i svojstva nizkokristallicheskih poliolefinov, modificirovannyh nanoalmazami. Vysokomolekuljarnye soedinenija. 2015. V. 57. No 6. S. 544-554. 


\section{RANDOM POLIPROPILENIN BUTADIEN-NITRIL KAUÇUKU ILə QARIŞIQLARININ Və ONLAR OSASINDA VULKANIZATLARIN REOLOJI XASSəLORİ}

\section{A.C.Quliyev, N.T.Qəhrəmanov, N.S.Koseva, N.B.Arzumanova}

İşdə butadien-nitril kauçukunun miqdarının və temperaturun random polipropilen əsasında polimer qarışıqlarının axma əyrilərinə təsirinin tədqiqinin nəticələri verilmişdir. Polimer qarışıqlarının texnoloji uyğunluğunun yaxşılaşdırılması üçün kompatibilizator kimi polipropilenin malein anhidridi ilə tikilmiş birgəpolimerindən istifadə olunmuşdur. Orintinin özlülüyünün temperaturdan və yerdəyişmə sürətindən asılılığı göstərilmiş, özlü axmanın aktivləşmə enerjisi müəyyən olunmuşdur. Real emal şəraitinə yaxın yüksək yerdəyişmə sürətlərində polimer qarışıqlarının effektiv özülüyünün qiymətini proqnozlaşdırmağa imkan verən polimer qarışıqların özlülük xassələrinin ümumiləşdirilmiş temperatur-invariant xüsusiyyəti qurulmuşdur.

Açar sözlər: butadien-nitril kauçuku, uyğunluq, arintinin özlülüyü, reologiya, aktivləşmə enerjisi, kompatibilizator.

\section{РЕОЛОГИЧЕСКИЕ СВОЙСТВА СМЕСЕЙ РАНДОМ ПОЛИПРОПИЛЕНА С БУТАДИЕН- НИТРИЛЬНЫМ КАУЧУКОМ И ВУЛКАНИЗАТОВ НА ИХ ОСНОВЕ}

\section{А.Д.Гулиев, Н.Т.Кахраманов, Н.С.Косева, Н.Б.Арзуманова}

В статье приводятся результаты исследования влияния концентрации бутадиен-нитрильного каучука и температуры на кривые течения полимерных смесей на основе рандом полипропилена. Для улучшения технологической совместимости полимерных смесей в качестве компатибилизатора использовали привитой сополимер полипропилена с малеиновым ангидридом. Показана зависимость вязкости расплава от температуры и скорости сдвига, определена энергия активации вязкого течения. Построена обобщенная температурноинвариантная характеристика вязкостных свойств полимерных смесей, позволяющая прогнозировать значение их эффективной вязкости при высоких скоростях сдвига, близких к реальным условиям переработки.

Ключевые слова: бутадиен-нитрильный каучук, совместимость, вязкость расплава, реология, энергия активации, компатибилизатор. 